\title{
THE EFFECTS OF ICT TOWARDS STUDENTS' ATTITUDE
}

\section{Wan Elisa Wan Hoesni' ${ }^{1}$, Fatin Nabilah Abu Hassan², Muhammad Talhah Ajmain @Jima'ain³, Nurul Atika Mohd Rosli4}

\author{
1Faculty of Education, Universiti Malaya,Malaysia \\ 2Faculty of Educational Studies, Universiti Putra Malaysia, Malaysia, \\ 3,4Faculty Social Sciences and Humanities, Universiti Teknologi Malaysia, Malaysia, \\ E-mail: elisahoesni@yahoo.com
}

\begin{abstract}
Advancement of Information and communication technology (ICT) rapidly transform many sectors and it does give and impact also to the educational field. Ministry of Education Malaysia starts to plan the curriculum to include ICT and teacher starts exploring different method and teaching style to develop students higher order thinking skills. Teacher plays an important role in designing lesson to integrate ICT as it will give effect to students' attitude in learning. The purpose of this study is to determine the effects of ICT towards students' attitude. The methodology of study utilized a systematic document analysis technique where issues related to effect ICT towards student attitude which have given impact to the teachers' and students' behavior in the form of any reference are analyzed. SAMR model will show that there is different level of degree of ICT integration that teacher can use and implement in class. Results shows that when ICT is use in class it will give an advantage in terms of student performances, motivation and efficiency. The student and classroom environment itself will be dynamic, active listening, collaborative learning, interactivity and communication will take place. Maximizing ICT potential can create and enhance learning to take place more effectively and transforming from teacher-centered to student-centered learning which are in line with the $21^{\text {st }}$ century goals.
\end{abstract}

Keywords: ICT, Student, Attitude

\begin{abstract}
ABSTRAK
Kemajuan teknologi informasi dan komunikasi (TIK) yang sangat pesat mengubah banyak sektor dan memberikan dampak juga bagi bidang pendidikan. Kementerian Pendidikan Malaysia mulai merencanakan kurikulum untuk memasukkan TIK dan guru mulai mengeksplorasi metode dan gaya mengajar yang berbeda untuk mengembangkan keterampilan berpikir tingkat tinggi kepada siswa. Guru berperan penting dalam merancang pembelajaran untuk mengintegrasikan TIK karena akan berpengaruh pada sikap siswa dalam pembelajaran. Tujuan dari penelitian ini adalah untuk mengetahui pengaruh TIK terhadap sikap siswa. Metodologi penelitian menggunakan teknik analisis dokumen sistematis dimana isu-isu yang berkaitan dengan pengaruh TIK terhadap sikap siswa yang berdampak pada perilaku guru dan siswa dalam bentuk referensi dianalisis. Model SAMR akan menunjukkan bahwa ada perbedaan tingkat integrasi TIK yang dapat digunakan dan diterapkan oleh guru di kelas. Hasil penelitian menunjukkan bahwa penggunaan TIK di kelas akan memberikan keuntungan dalam hal kinerja, motivasi dan efisiensi siswa. Siswa dan lingkungan kelas itu sendiri akan dinamis, mendengarkan secara aktif, pembelajaran kolaboratif, interaktivitas dan komunikasi akan berlangsung. Memaksimalkan potensi TIK dapat menciptakan dan meningkatkan pembelajaran agar berlangsung lebih efektif dan berubah dari pembelajaran yang berpusat pada guru menjadi pembelajaran yang berpusat pada siswa yang sejalan dengan tujuan abad ke-21.
\end{abstract}

Kata Kunci: TIK, Mahasiswa, Sikap

* Copyright (c) 2020 Wan Elisa Wan Hoesni et.all

This work is licensed under a Creative Commons Attribution-ShareAlike 4.0 International License.

Received: 7 April 2020; Revised: 26 April 2020; Accepted: 29 April 2020 


\section{INTRODUCTION}

We are living in a $21^{\text {st }}$ century era in which the world is changing rapidly. The technology enhancement and advancement in the fourth revolution has transform the educational landscape. On top of that, students in elementary and secondary schools nowadays consist of those from Generation Z, who are also known as digital native and tech-savvy kids (Hasmawati, Samiha, Razzaq, \& Anshari, 2020). Gen Z are those born between 1995-2012. They are often being characterized as multi-taskers, risk-takers, individualistic, more entrepreneurial and global. This is due to the high accessibility to technology and ICT since they were kids. The accessibility to technology and ICT somehow playing roles in shaping their growth, personality and attitude. Therefore, in order to ensure the learning process is still relevant and meaningful to this generation, the elements in education such as teaching, and learning has to be aligned with their needs.

In response to that, Malaysian Ministry of Education has transformed its education system by introducing the Malaysia Education Blueprint back in 2012. The blueprint emphasizes more on the inculcation of ICT in education to provide student-centered, deep and meaningful learning to the students (Ministry of Education, 2013). Teachers started to explore various learning strategies that adopted ICT in their teaching styles to develop students higher order thinking such as integration of augmented reality and virtual reality technology in problem-based learning, project-based learning as well as inquiry-based learning.

Several previous studies on ICT have been conducted by Ziden et al (2011) about The Effects of ICT Use in Teaching and Learning on Students' Achievement in Science Subject in a Primary School in Malaysia. And Umar \& Hassan (2015) about Malaysian teachers' levels of ICT integration and its perceived impact on teaching and learning. What distinguishes this research from previous research is the aims and methods of the researchers. In this paper, we aims to explore the effects of ICT in education towards students attitude.

\section{RESEARCH METHOD}

This study utilized a systematic document analysis technique which is under one of the branches of qualitative method. This was seen to be a suitable method as this study analysed a collection of data as defined by the following:

"Document analysis is just what its name implies - the analysis of the written or visual contents of a document. Textbooks, essays, newspapers, novels, magazine articles, cookbooks, political speeches, advertisements, pictures - in fact, the content of virtually any type of written or visual communication can be analyzed in various ways. A person"s or group"s conscious beliefs, attitudes, values, and ideas are often revealed in the document they produce (Fraenkel, Wallen, \& Hyun, 1993)."

Qualitative data in descriptive form, pertaining human behaviour or current events (Jasmi, 2012) are issues related to effect ICT towards student attitude which have given impact to the teachers' and students' behaviour. Therefore, this research employed references like journals, books, articles, seminars, and research articles on effects of ICT on student. After data from different resources were collected, they were analysed and served as reference for this research and hope to assist future researches as well. 


\section{RESULTS AND DISCUSSION}

\section{ICT in Education}

ICT is essential in running various sectors like economy, industries and education. The implementation of ICT in education has change the way teaching and learning is conducted in class (Mallahi \& Mohamed, 2019). The advancement in technology causing the exchange of information to be simplified as it is no longer bounded by the geographical distance. Thus, the implementation of ICT in education will enhance the process of fostering knowledge and assuring students to become future specialists who are capable to expand the knowledge (Krishnaveni \& Meenakumari, 2010). Teachers are adapting with these changes and need to learn on how to integrate ICT in their teaching and learning. There is one concept which is the pedagogical Integration of ICT whereby it is not just having ICT being install and being use but to include the use of technology as tools in school to improve learning and facilitate educational development. It also defined as the process of choosing the most suitable and the most appropriate use of interactive technology to gives a beneficial changes in student learning (Ngamo, 2017).

\section{SAMR Model}

In order to integrate the technology in the classroom, SAMR Model has been develop by Dr. Ruben Puentedura as a framework From figure 1. It can be categorized into four degrees of classroom technology integration which are Substitution, Augmentation, Modification and Redefinition. This model represents a ladder which moves from bottom to the top (Hamilton, Rosenberg, \& Akcaoglu, 2016).

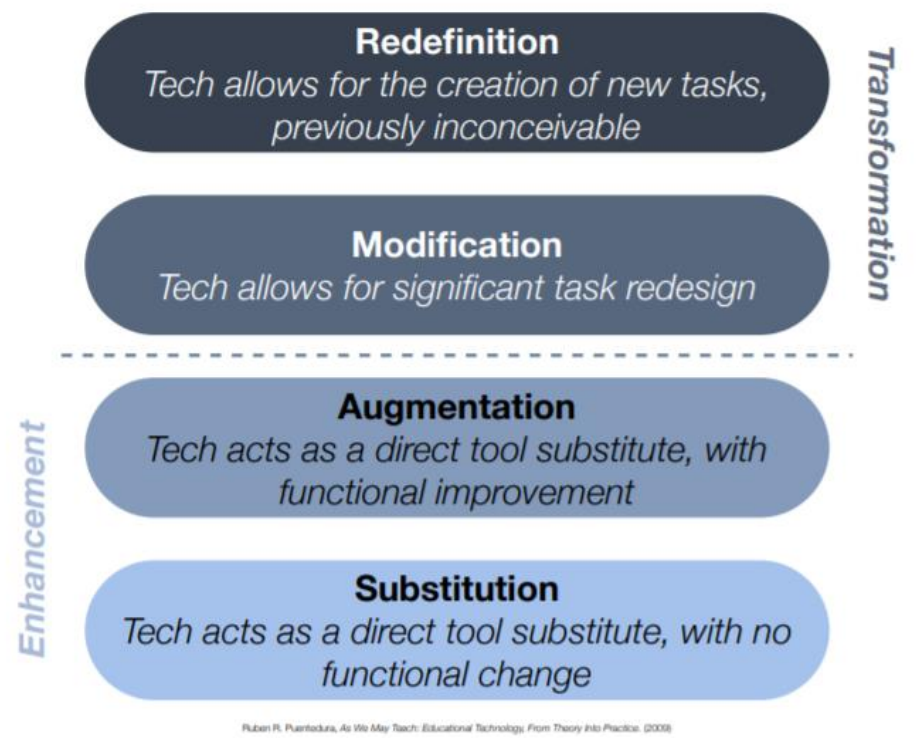

\section{Figure 1. Puentedura's (2014) Substitution, Augmentation, Modification, and Redefinition (SAMR) model (retrieved from http://www.hippasus. com/rrpweblog/)}

This model function like a lens, which helps educator to see how they should use this technology in classroom. The SAMR model is derived from the initials of four words which are Substitution, Augmentation, Modification and Redefinition. The first two levels are Substitution and Augmentation 
where it acts as an enhancement while the real function of technology takes place when it comes to transformation level which are Modification and Redefinition (Puentedura, 2012).

Substitution is replacing the existing tools that are used in traditional classroom to use technology such as using word processor to replace pens and paper. Next is augmentation, whereby it provides more substitution and provide more changes in some ways. For example, teacher is using hand held device to allows student watching videos and playing digital stories. The hand held devices augment the reading task (Hamilton et al., 2016). Modification is where tasks are redesign. Example for this is when the teacher allow collaborative using technology such as writing collaborative report using Google Docs and using forum to conduct discussion. Finally, Redefinition is the highest level where technology is used to achieve novel task, which is not inconvincible in the traditional classroom. For example, teacher can ask student to produce the assignment in a video form and uploaded on the social media. Thus teacher need to explore and select the tools available to make the lesson integrate with technology better.

\section{The Usage of ICT for Various Functions}

The evolution of the web producing a lot of new platform with its specific function. Firstly, teacher need to learn on the available tools that is available on the web. SAMR Model can be a guideline on what level the teacher wants the technology to be integrate in the classroom. Web 2.0 provides and enable a new level of interaction and communication between users, for sharing and creating online content including educational content (García-Barriocanal, Sicilia, Sánchez-Alonso, \& Lytras, 2011). Thus, teacher need to know what the available tools are to be use in class. Youtube is one of the platforms where anyone can use and upload videos. It is considered as Open Educational Resources (OER) defined as "digitalized materials offered freely and openly to educators, students and independent learners" facilitate access knowledge. Thus, teacher can use Youtube as a platform to upload material and also use any content from the Youtube as a resource in class. Another Web 2.0 tool is Mentimeter where user can anonymously answer the question. This could be beneficial to test the understanding of the student in independent way. It also can increase engagement, for those participants who are reluctant or shy to share their answer (Rudolph, 2018). The advantage of teacher using ICT tools is that teacher will get each student responses respectively with their self-pace.

Another important part in education is the assessment. When implementing ICT in class, digital assessment is important in terms of feedback, control of the learning rates that vary from individual to individual and learning quality to be achieved at the end of the assessment process. Continuous measurement and evaluation activities should be carried out in digital education in order to avoid problems and to check understanding (Çetİn, 2018). Web 2.0 tools are made to allow interaction and communication between user. Thus, the tools are to be fully utilized for educational purposes to create student-centered environment. A study by Ismail \& Mohammad (2017) shows that students are more engaging and see that the Kahoot is more fun activity. Students are likely to spend more time to study if it is enjoyable, fun and engaging (Glonek, 2013). This shows that there are a lot of ICT tools readily available, but teachers need to explore and choose the tools accordingly to ensure the effectiveness of the tools. The best is when teachers able to reach Redefinition level based on the SAMR model.

\section{The Concept of Education}

Education is one of the major agendas that can affect the quality and civilization of a nation in the world (Samian \& Awang, 2017). The education process will take place throughout the human life (Shazila, 
2015). Starts in the mother content until the end of the life. The educational phase will take place in human life either in formal or informal.

In this educational process, man awakens all potential that exist to include potential of reason (cognitive), physical/behavioural (psychomotor/behaviour), Spiritual (afaktif) (Tamuri \& Ajuhary, 2010). All of these potentials are experiencing developments in human life starting from birth. The development of these potentials can increase the capacity of intellectual power, proficiency and sensitivity to the social environment, especially through a point of teaching. This corresponds to the definition of the encyclopedia:

"Process, beginning at birth, of developing intellectual capacity, skills, and social awareness, especially by instruction".

According to the Dictionary (2020), Education also refers to:

"The act or process of imparting or acquiring general knowledge, developing the powers of reasoning and judgment, and generally of preparing oneself or others intellectually for mature life."

Education means a process to deliver and gain knowledge to develop intellectual and human confidence so as to change the behavior and response of a person's attitude. In addition, education according to Ghazzālī \& Faris (2009) is educating by giving priority to the individual and making excellent people who are educated with good nature and Syahsiah. Thus, in brief, education means all experiences gained through the senses affect human thinking. Information that is structured will form physical and human behavior. Knowledge, skills and values will be inherited from generation to the generation in the process of developing the nation's national civilization continuously.

\section{Information and Communications Technology (ICT)}

The ICT abbreviation stands for Information and Communication Technology. According to Ajayi (2008), it is defined as a set of activities and processes and resources used it to communicate, create, disseminate, store and manage information. Hamidi, Meshkat, Rezaee, \& Jafari (2011) explained which ICT was indeed divided into two main approaches to education, such as ICT besides education and ICT for education. ICT for education requires the generation of information and communications technologies for teaching and learning purposes, while ICT for education involves the adoption of general components of information and communications technologies for practical use in teaching and learning processes.

ICT encompasses all those gadgets that deal with the processing of information for cheaper and more accurate communication (UGWU \& Nnaekwe, 2019). According to UNESCO, "ICT is a scientific , technological and engineering discipline and management technique used in the protection of information, its application and its association with social , economic and cultural problems" (Ratheeswari, 2018). In education, the communication process takes place between teachers, students, team leaders and staff, going to require a big quantities of data to be stored for retrieval as and when possible, to be disseminated or transmitted in the desired format. In education, the communication process takes place between teachers, students, team leaders and staff, going to require a big quantities of data to be stored for retrieval as or where possible to be disseminated or transmitted in the format demanded. ICTs are making dynamic changes in the society. Influences are strongly realized in schools (Ratheeswari, 2018). Because ICTs provide both students and teachers with more opportunities to adapt learning and teaching to individual needs, society and more innovation will have an impact on the attitudes. 


\section{The Concept of Attitude}

According to Abd Latiff (Abd Latiff, 2004), the attitude can be construed as a holding based on one belief, while thought is a set of views concluded as a pattern of truth or consideration. The process of forming attitudes is the source of knowledge and information absorbed into the thought and next the analysis and evaluation process so as to achieve the level of trust and confidence (Nordin \& Ling, 2011). Thus, the confidence leads to a attitude, leading to the creation of a character or the characters. The representation of a person's attitude and thought is through words, behavior and actions.

(RAZALI, 2014) defines the attitude as part of an individual personality that is influenced by the group's behavior of a relationship with him. Attitudes can also be defined as a tendency to act on someone, object, incident or idea. It arises not to be noticed, lasting and in close contact with opinions. It formed a result of learning experience. Hill (2017) defines attitude as a condition of mental and nervous readiness, structured through experience, motivate One direction, or to dynamically influence individual reactions to all objects and situations related to it.

According to Aiken (1976) and Şimşekoğlu (2015), attitudes are an internal representation of individuals who refer to the tendency to behave positive or negative to the objects, situations, institutions, concepts or other individuals, and attitudes closely with changes and influence. Several previous

literature surveys have shown that there is a close correlation between attitudes and the use of information technology with teaching in classrooms (Krishnan, Janarthini, Mohamad Said, Mohd. Nihra. Haruzuan, 2007).

In a study involving the use of computers in four schools in the United States, the consistent information technology training against staff has been identified as a significant factor that fosters positive attitude among the teachers in turn leads to changes in the professional activities of teachers in information technology after two years (Rockman, Pershing \& Ware, 1992 in Soon Yin \& Kooi (2002).

The conclusion that we can understand that, in describing the concept of education, ICT and attitude, it tells us there is a significant association between these three namely education is changing, ICT is also the environment that makes up the change, while the attitude is the object that changed. This shows that there is a relationship between ICT and the attitude in education.

\section{The Advantages of ICT in Education}

ICT can be known to facilitate teaching and learning (T\&L) and it had been widely used in every layers of education. The implementation of ICT in learning can provide considerable benefits which can be seen from student performance, motivation and efficiency and summarize in figure 1. Amongst the advantages of ICT in education is active learning (Huffaker, 2003). Active learning includes all kinds of learning beyond the mere one-way transmission of knowledge in lecture-style classes (passive learning) where in requires engagement in activities such as writing, discussion and presentation (Matsushita, 2017). It includes externalizing cognitive process in the activities such as process of perception, memory, language and thinking. By using technology in student's learning, the students can be active learners when the ICT integration is done properly in class. They will be aware of what information they need, why they need it, and how they can get that information.

Active learners need to decide by themselves when they require particular information and whether they have already understood that information or not. Among active learning strategies may include in and out of class activities, cooperative and collaborative learning and it involve technology tools (Misseyanni, Papadopoulou, Marouli, \& Lytras, 2018). Teachers who adapt active learning would be serve as facilitators where teacher would spend more time helping student develop their understanding and 
other skills which promote deeper learning instead of lecturing and transmitting information. By having access to internet in their school the students will not totally depend on the teachers. They can explore information available in the internet, find information that they need, copy it, and go on to find more and more information. By using this learning system, the students also become self-managed in their learning process. This would expand and nurture students mind enhancing more skills that can be used in future.

Other than that, ICT enhances dynamic and collaborative learning where internet can serve as medium that bring together teachers and student without demographically and time restriction. Since internet were accessible at anytime and anywhere thus it allows student to access knowledge readily. It also helps rural student to access information from urban areas, getting information and sharing of knowledge with other students and teachers in the same areas or even different countries. It also helps parents and administrator to supervise students and getting or giving feedback simultaneously. Collaborative learning involving working together in group to solve a problem, completing a task or collaborate on a project (Shonfeld \& Gibson, 2018). By working together with peers, it would help student to engage socially with their peers, help them to handle problem maturely and also enhance leadership skills.

ICT also had done some revolution in education field where it enhance interactivity and communication during teaching by teachers and students. As mentioned by Ghavifekr, Kunjappan, Ramasamy, \& Anthony (2016) "effective learning happens when students are interactively engaged in a learning task." Learning using ICT is more than learning through memorization. It allows the learners to experience their learning processes, being interactive, enjoy and have fun with technology. By entering the era of Industrial Revolution 4.0, there were lot of websites that offers interactive learning like Kahoot, Quizziz, Mentimeter and many more. The diversity of students in the class should be taken into account for every teacher to design class with high interactivity in order to capture the attention of different type of learners in class where some of them were audio learner, visual learner or kinesthetic learners. This would also help student to be actively engaged in learning when the learners can interact and getting feedback continuously from their teachers (Huffaker, 2003).

According to Higgins et al (2012), digital technology is best used as a supplement to normal teaching rather than as a replacement for it because it is not the problem whether technology is used which makes the difference but how well the technology is applied to support teaching and learning by teachers. Teachers should have quality teaching and the ability to use the digital equipment and tools effectively for lesson that include videos and animations to help students to understand more about complex theories and concept. In conclusion, in order to ensure ICT would give positive impact on teaching and learning, teachers need to incorporate technology and normal teaching to increase the effectiveness of teaching and learning in future. SAMR model is a good reference to enhance which degree of ICT intergration environment that the teacher wants to create you can see in figure 2.

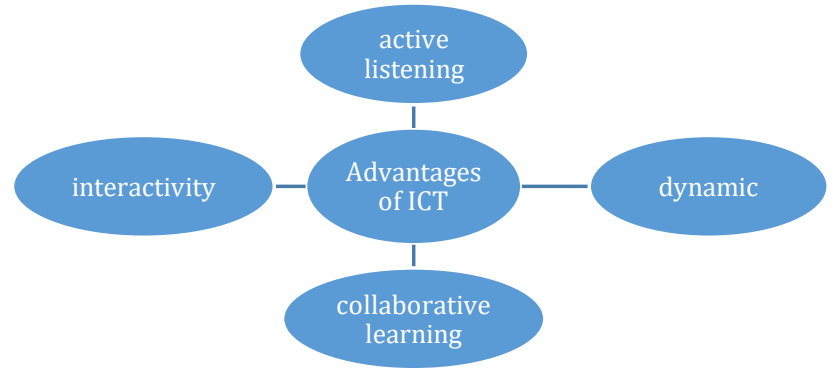

Figure 2. Summary of the advantages of ICT on Education 


\section{CONCLUSION}

In conclusion, this paper use SAMR Model as a framework in reviewing how the educators integrating technology in their classrooms. The review on past literatures revealed that the usage of ICT in education enhance student-centered learning whereby the students become active and independent learners that keen to explore and discover knowledge. The students also found to be more dynamic and collaborative as they learn to work with their peers in completing the learning activities and tasks. On top of that, it enhances their communication skills as they manage to communicate and deliver their idea effectively with their teachers and peers. These are in line with the 21st century learning goals which to.

\section{REFERENCES}

Abd Latiff, A. Z. (2004). Teori perubahan sikap ke arah menjana kecemerlangan dalam kepimpinan/Dr. Ahmad Zaki Hj. Abd Latiff. Jurnal Akademik UiTM Cawangan Johor, 4(1), 79-86.

Aiken Jr, L. R. (1976). Update on attitudes and other affective variables in learning mathematics. Review of Educational Research, 46(2), 293-311.

Ajayi, I. A. (2008). Towards effective use of information and communication technology for teaching in nigerian colleges of education. Asian J. Inf. Technol, 7(5), 210-214.

Çetİn, H. S. (2018). Implementation of the Digital Assessment Tool ‘ Kahoot !' i n Elementary School. International Technology and Education Journal, 2(1), 9-20.

Dictionary. (2020). Education. Retrieved from https://www.dictionary.com/browse/education

Fraenkel, J. R., Wallen, N. E., \& Hyun, H. H. (1993). How to design and evaluate research in education (Vol. 7). McGraw-Hill New York.

García-Barriocanal, E., Sicilia, M. A., Sánchez-Alonso, S., \& Lytras, M. (2011). Semantic annotation of video fragments as learning objects: A case study with YouTube videos and the Gene Ontology. Interactive Learning Environments, 19(1), 25-44. https://doi.org/10.1080/10494820.2011.528879

Ghavifekr, S., Kunjappan, T., Ramasamy, L., \& Anthony, A. (2016). Teaching and Learning with ICT Tools: Issues and Challenges from Teachers' Perceptions. Malaysian Online Journal of Educational Technology, 4(2), 38-57.

Ghazzālī, \& Faris, N. A. (2009). The Book of knowledge. Adam Publishers \& Distributors.

Glonek, J. G. (2013). Learning styles: Theories and pedagogical strategies. United States Military Academy.

Hamidi, F., Meshkat, M., Rezaee, M., \& Jafari, M. (2011). Information technology in education. Procedia Computer Science, 3, 369-373.

Hamilton, E. R., Rosenberg, J. M., \& Akcaoglu, M. (2016). The Substitution Augmentation Modification Redefinition (SAMR) Model: a Critical Review and Suggestions for its Use. TechTrends, 60(5), 433-441. https://doi.org/10.1007/s11528-016-0091-y

Hasmawati, F., Samiha, Y. T., Razzaq, A., \& Anshari, M. (2020). UNDERSTANDING NOMOPHOBIA AMONG DIGITAL NATIVES: CHARACTERISTICS AND CHALLENGES. Journal of Critical Reviews, 7(13), 122-131.

Higgins, S., Xiao, Z., \& Katsipataki, M. (2012). The impact of digital technology on learning: A summary for the education endowment foundation. Durham, UK: Education Endowment Foundation and Durham University.

Hill, R. J. (2017). Attitudes and behavior. In Social Psychology (pp. 347-377). Routledge.

Huffaker, D. (2003). Reconnecting the classroom: E-learning pedagogy in US public high schools. Australasian Journal of Educational Technology, 19(3). 
Ismail, M. A.-A., \& Mohammad, J. A.-M. (2017). Kahoot: A Promising Tool for Formative Assessment in Medical Education. Education in Medicine Journal, 9(2), 19-26. https://doi.org/10.21315/eimj2017.9.2.2

Jasmi, K. A. (2012). Metodologi Pengumpulan Data dalam Penyelidikan Kualitatitif. Kursus Penyelidikan Kualitatif Siri 12012.

Krishnan, Janarthini, Mohamad Said, Mohd. Nihra. Haruzuan, N. A. (2007). Faktor-faktor yang Mempengaruhi Penggunaan E-Pembelajaran di kalangan Pelajar Tahun Akhir Fakulti Pendidikan, Universiti Teknologi Malaysia. Smart Teaching \& Learning. Utilization and Innovation of Technology, 1(1), 6-12.

Krishnaveni, D. R., \& Meenakumari, J. (2010). Usage of ICT for Information Administration in Higher education Institutions - A study. International Journal of Environmental Science and Development, 1(3), 282-286. https://doi.org/10.7763/ijesd.2010.v1.55

Mallahi, H., \& Mohamed, L. (2019). Students ' Attitudes towards ICT and their Achievement i $n$ English Contextualization of the study Statement of the problem : Objective of the study: Identification of the population: Instruments : Data analysis : Discussion of the results: African Journal of Education, Science and Technology, 1-4.

Matsushita, K. (2017). Deep Active Learning: toward greater depth in university education. Singapore: Springer.

Misseyanni, A., Papadopoulou, P., Marouli, C., \& Lytras, M. D. (2018). Active learning stories in higher education: Lessons learned and good practices in STEM education. In Active Learning Strategies in Higher Education. Emerald Publishing Limited.

Ngamo, S. (2017). ICT INTERGRATION IN PHYSICS.

Nordin, A., \& Ling, L. H. (2011). Hubungan sikap terhadap mata pelajaran sains dengan penguasaan konsep asas sains pelajar tingkatan dua. Journal of Science \& Mathematics Educational, 2, 89-101.

Puentedura, R. R. (2012). SAMR: Thoughts for Design. 11.

Puentedura, R. R. (2014). SAMR and TPCK: A hands-on approach to classroom practice. Hipassus. En Ligne: Http://Www. Hippasus. Com/Rrpweblog/Archives/2012/09/03/BuildingUponSA M R. Pdf.

Ratheeswari, K. (2018). Information communication technology in education. Journal of Applied and Advanced Research, 3(1), S45-S47.

RAZALI, F. B. (2014). MODEL PEMBENTUKAN MINAT KERJAYA SAINS, TEKNOLOGI, KEJURUTERAAN DAN MATEMATIK DALAM KALANGAN PELAJAR ALIRAN SAINS TINGKATAN EMPAT DI SELANGOR, MALAYSIA.

Rudolph, J. (2018). A brief review on mentimeter - A student response system. Journal of Applied Learning \& Teaching, 1(1), 35-37.

Samian, S., \& Awang, A. (2017). Pendidikan Sebagai Komponen Kualiti Hidup Masyarakat Pinggir Bandar (Education As Quality Components Of Life In The Suburban Community). Asian Journal Of Environment, History And Heritage, 1(1).

Shazila, I. (2015). MEMBUDAYAKAN PEMBELAJARAN SEPANJANG HAYAT DI MALAYSIA. Jurnal UTHM, 1, 90-95.

Shonfeld, M., \& Gibson, D. (2018). Collaborative learning in a global world. IAP.

Şimşekoğlu, Ö. (2015). How do attitudes, personality traits, and driver behaviors relate to pedestrian behaviors?: A Turkish case. Traffic Injury Prevention, 16(1), 84-89.

Soon Yin, T., \& Kooi Guan, C. (2002). Latihan dan penggunaan teknologi dalam pengajaranpembelajaran guru-guru. Jurnal Pendidikan Guru, 2(2), 62-72.

Tamuri, A. H., \& Ajuhary, M. K. A. (2010). Amalan Pengajaran Guru Pendidikan Islam Berkesan Berteraskan Konsep Mu 'allim. Journal of Islamic and Arabic Education, 2(1), 43-56.

UGWU, N. P., \& Nnaekwe, K. (2019). THE CONCEPT AND APPLICATION OF ICT TO TEACHING/LEARNING PROCESS. International Research Journal of Mathematics, Engineering and IT, 6(2). 
Khazanah Pendidikan Islam, Vol. 2 No. 2: 90-99

The Effects of ICT Towards Students' Attitude

Wan Elisa Wan Hoesni et.all

Umar, I. N., \& Hassan, A. S. A. (2015). Malaysian teachers' levels of ICT integration and its perceived impact on teaching and learning. Procedia-Social and Behavioral Sciences, 197.

Ziden, A. A., Ismail, I., Spian, R., \& Kumutha, K. (2011). The Effects of ICT Use in Teaching and Learning on Students' Achievement in Science Subject in a Primary School in Malaysia. Malaysian Journal of Distance Education, 13(2). 